\title{
Biology of the subtropical sac-spawning euphausiid Nyctiphanes simplex in the northwestern seas of Mexico: Vertical and horizontal distribution patterns and seasonal variability of brood size
}

\author{
Jaime Gómez-Gutiérrez $^{\mathrm{a}, *}$, Nelly Tremblay ${ }^{\mathrm{a}}$, Samuel Martínez-Gómez ${ }^{\mathrm{a}}$, Carlos J. Robinson ${ }^{\mathrm{b}}$, \\ Jorge Del Ángel-Rodríguez ${ }^{\mathrm{a}, \mathrm{c}}$, Carmen Rodríguez-Jaramillo ${ }^{\mathrm{c}}$, Christian Zavala-Hernández ${ }^{\mathrm{a}}$ \\ ${ }^{a}$ Centro Interdisciplinario de Ciencias Marinas, Departamento de Plancton y Ecología Marina, Av. IPN, Col. Palo de Santa Rita s/n, La Paz, Baja California Sur 23096, Mexico \\ ${ }^{\mathrm{b}}$ Instituto de Ciencias del Mar y Limnología, Universidad Nacional Autónoma de México, Laboratorio de Ecología de Pesquerías, A.P. 70-305, D.F. 04510, Mexico \\ ${ }^{\mathrm{c}}$ Centro de Investigaciones Biológicas del Noroeste, Mar Bermejo No. 195, Col. Playa Palo de Santa Rita, La Paz, Baja California Sur 23096, Mexico
}

\section{A R T I C L E I N F O}

\section{Article history:}

Accepted 30 October 2009

Available online 10 November 2009

Topical issue on "Krill Biology and Ecology." The issue is compiled and guest-edited by the North Pacific Marine Science Organization (PICES), International Council for the Exploration of the Sea (ICES), and Global Ocean Ecosystem Dynamics (GLOBEC) project.

\section{Keywords:}

Nyctiphanes simplex

Horizontal and vertical distribution

Brood size

Seasonal thermocline

Low oxygen layer

Gulf of California

\begin{abstract}
A B S T R A C T
Vertical and horizontal distributions of the subtropical euphausiid juvenile and adult Nyctiphanes simplex were mapped from samples collected during winter and summer 2007 in the Gulf of California, Mexico. During winter, wide-ranging high densities occurred in most of the Gulf of California. Densities decreased considerably during summer, with only at few locations having high densities. $N$. simplex made short daily vertical migrations of $<150 \mathrm{~m}$ with pronounced vertical seasonal ontogenetic segregation. In winter, most life stages, particularly gravid and ovigerous females, were found in the top $100 \mathrm{~m}$ at night, with temperatures $<17{ }^{\circ} \mathrm{C}$ throughout the normal, cold, well-mixed water column. During summer, a seasonal thermocline at $\sim 50 \mathrm{~m}$ formed with temperatures between $22-29{ }^{\circ} \mathrm{C}$ above the thermocline. Reproductive females and males were found below the thermocline at $>50 \mathrm{~m}$, clearly avoiding layers with temperatures $>20^{\circ} \mathrm{C}$. In both seasons, $N$. simplex occurred above the low-oxygen layer $\left(<1.5 \mathrm{ml} \mathrm{l}^{-1}\right)$, which occurred at $150 \mathrm{~m}$ during winter and $90 \mathrm{~m}$ during summer. In summer, this layer extended farther north and into shallower water columns than during winter. The low-oxygen layer acts as the bottom limit of vertical distribution and horizontal distribution is limited at the southern part of the gulf to temperatures $>23^{\circ} \mathrm{C}$. Seasonal brood size and reproductive effort were estimated for both sides of the Baja California Peninsula under ship board experiments as a proxy of the relative effect of seasonal environmental conditions for euphausiid reproduction. Experiments were done during March, July, and December 2004 at the entrance to Bahía Magdalena and its westward continental shelf and in November 2005 and January and July 2007 in the Gulf of California. Contrary to broadcast-spawning euphausiids, $N$. simplex, a sac-spawning euphausiid, has a significant association of the brood size as a function of the total length of females. N. simplex produces an average brood of 52 eggs female ${ }^{-1}$ (range $5-116$ eggs female ${ }^{-1}$ ) with a estimated total fecundity of 936 eggs female $^{-1}$ in a life span (360-1337 eggs female $\left.{ }^{-1}\right)$, of which about $8 \%$ of its carbon weight is released per spawn, significantly higher than estimates of previous studies. In Bahía Magdalena, broods contained more embryos in March and July 2004 than in December 2004 when temperatures increased to $>23{ }^{\circ} \mathrm{C}$. In the Gulf of California, broods had higher numbers of embryos in November and July than in January 2007, suggesting that $N$. simplex has an out-of-phase reproductive season on both coasts of the peninsula. Reproductive investment effort was larger in the Gulf of California than in Bahía Magdalena, where females generated up to $18.3 \%$ of their weight in their broods, primarily by brood sizes produced from females between 10-12 mm total length that were particularly fecund during November and July. (c) 2009 Elsevier Ltd. All rights reserved.
\end{abstract}

\footnotetext{
* Corresponding author. Tel.: +52 612123 4666; fax: +526121220350.

E-mail address: jagomezg@ipn.mx (J. Gómez-Gutiérrez).
}

\section{Introduction}

Nyctiphanes simplex is a subtropical sac-spawning euphausiid that dominates, in terms of biomass and abundance, the neritic environment over the continental shelf of the northern and southern Eastern Pacific Ocean. This krill has a central area of higher density along the west coast of the Baja California 
Peninsula and the Gulf of California considerably decreasing in abundance in equatorial waters and having another center of distribution within the northern part of the Humboldt Current System (Brinton, 1962, 1979; Brinton and Townsend, 1980; Brinton et al., 2000; Gómez-Gutiérrez, 1995; Gómez-Gutiérrez et al., 1995). In the northern hemisphere, its interannual occurrence extends north to British Columbia (Tanasichuk and Cooper, 2002) or Oregon (Brodeur, 1986) during strong El Niño events.

Nyctiphanes simplex forms dense swarms that attract many predators, some of them are highly specialized and feed exclusively on euphausiids (stenophagous), like blue and fin whales, mantas, and whale sharks (Gendron, 1992; Ladrón de Guevara et al., 2008). Its seasonal distribution and abundance have been studied along the west coast of the Baja California Peninsula (Brinton, 1962; Lavaniegos, 1995, 1996; GómezGutiérrez, 1995, 1996; Gómez-Gutiérrez et al., 1995) and the Gulf of California (Brinton and Townsend, 1980; De Silva-Dávila et al., 2002; Gendron, 1992; Lavaniegos, 1987, 1988; Lavaniegos et al., 1989) mostly using vertically integrated oblique bongo net tows. Brinton and Townsend (1980) was the first, and, so far, more extensive study (samples collected in 1957) to understand monthly and seasonal variability of abundance and horizontal distribution of $N$. simplex in the gulf. They recognized this species has a widespread distribution most of the year, but with significantly declining abundance and retraction of its distribution northward during the summer (August and September). De SilvaDávila and Palomares-García (1998) observed a similar seasonal reduction of population abundance from winter to summer in Bahía de La Paz on the southwest coast of the peninsula in the gulf.

Several studies report daily vertical movements (DVM) of $<150 \mathrm{~m}$, although $N$. simplex specimens were sometimes collected as deep as $280 \mathrm{~m}$ (Brinton, 1962, 1967, 1979; GómezGutiérrez et al., 1999; Lavaniegos, 1996) but seasonal variability has not been studied. Hydroacoustic information has shown that $N$. simplex has a more variable vertical behavior that previously thought, inhabiting the near-demersal environment during the day (Robinson and Gómez-Gutiérrez, 1998) or any time in shallow mouth of bays < $40 \mathrm{~m}$ (Gómez-Gutiérrez and Robinson, 2006). Only two previous studies investigated the DVM of $N$. simplex in the Gulf of California, both carried out during winter (Brinton, 1979; Lavaniegos, 1996). The first was part of a latitudinal transect $\left(26^{\circ} \mathrm{N}\right.$ to $\left.11^{\circ} \mathrm{S}\right)$ that included three stations in the mouth of the gulf between Cabo San Lucas $\left(22^{\circ} \mathrm{N}\right)$ and Cabo Corrientes $\left(20^{\circ} \mathrm{N}\right)$ (Brinton, 1979). The other study included three stations during May 1965 located along the western and central part of the gulf $\left(29-27^{\circ} \mathrm{N}\right)$ (Lavaniegos, 1996, Fig. 1C). The seasonal variability of the DVM of the species in the gulf is currently unknown.

According to Hidalgo-González and Alvarez-Borrego (2000, $2004)$ the seasonality of integrated total $\left(\mathrm{PT}_{\mathrm{int}}\right)$ and new $\left(P_{\text {newint }}\right)$ primary production $\left(\mathrm{g} \mathrm{C} \mathrm{m}^{-2} \mathrm{~d}^{-1}\right)$ in the gulf is divided into two "seasons": cold (December-June, with values of 1.16-1.91 $\mathrm{g} \mathrm{C} \mathrm{m}^{-2} \mathrm{~d}^{-1}$ ) and warm (July-November, with values of $0.39-0.49 \mathrm{~g} \mathrm{C} \mathrm{m}^{-2} \mathrm{~d}^{-1}$ ), demonstrating a significant seasonal variability in food availability for herbivorous and omnivorous zooplankton. In the warm season, the water column is strongly stratified and the depth of the low oxygen layer is shallower than during the cold season (Brinton and Townsend, 1980; Badan-Dangon et al., 1985). According to Lavaniegos (1992), holozooplankton with life-cycle spans of several months, like $N$. simplex, with an average span of $\sim 8$ months (occasionally as long as 1 year), thus each generation is likely to be exposed to pronounced seasonal environmental changes typical of this subtropical gulf.
We compared horizontal and vertical movements by developmental stage during January (winter) and July (summer) 2007 to assess differences in seasonal three-dimensional distributions in the central and northern part of the gulf. This study was part of a multi-disciplinary effort to combine field data of vertical and horizontal distribution of krill with shipboard temperaturecontrolled incubations of $N$. simplex to determine seasonal variability of the mean brood size and reproductive effort covering six oceanographic cruises (2004-2007) along the southwest coast of the Baja California Peninsula (Pacific Ocean) and the central and southern Gulf of California of Mexico. Brood size and reproductive effort are two valuable biological measures of how $N$. simplex populations respond to seasonal environmental variability along the coasts of the Baja California Peninsula.

\section{Materials and methods}

Hydroacoustic and submarine videocamera surveys of two regions, both sides of the Baja California Peninsula, were made in 2004 and 2005-7 (Fig. 1A). Three oceanographic cruises covered the continental shelf and mouth of Bahía Magdalena $\left(24^{\circ} 30^{\prime} \mathrm{N}\right.$, $112^{\circ} 30^{\prime} \mathrm{W}$ ) on 16 March to 2 April, 28 June to 16 July, and 1 through 18 December 2004) (Fig. 1B) and three oceanographic cruises covered the central and southern gulf on 16 November through 3 December 2005, 12 through 31 January 2007, and 17 July through 3 August 2007 (Fig. 1C). All them were carried out on board the R/V 'B;El Puma'.

\subsection{Horizontal distributions in winter and summer in the Gulf of California}

Standard oblique tows with a bongo net (500 and $300-\mu \mathrm{m}$ mesh) equipped with a digital flow meter were used during all surveys (Smith and Richardson, 1979). The samples from the 500$\mu \mathrm{m}$ net were preserved with $70 \%$ ethanol, and the samples from the $300-\mu \mathrm{m}$ net were preserved with $10 \%$ formalin buffered with sodium borate. Samples of the $500-\mu \mathrm{m}$ net of January and July 2007 were analyzed to estimate contrasting seasonal horizontal distribution and abundance patterns (standardized as number of krill $1000 \mathrm{~m}^{-3}$ ) of juvenile and adult $N$. simplex. Relative abundance of ovigerous females during the 2007 surveys was calculated and plotted a map using SURFER software v. 8.0 to compare distributions and spawning areas in the gulf. This map was compared with the distribution of temperature measured every $5 \mathrm{sec}\left(\sim 50 \mathrm{~m}\right.$ resolution at a speed of $\left.\sim 18 \mathrm{~km} \mathrm{~h}^{-1}\right)$ along the path of the research vessel with a CTD sensor (SeaBird microcat) fixed to the vessel's hull at $4 \mathrm{~m}$ below the surface. In January 2007, 237,558 temperature measurements were made and in July 2007, 243,830 temperature measurements were made. All measurements were simultaneously geo-referenced at $\pm 1 \mathrm{~m}$ accuracy (Trimble AG160).

\subsection{Vertical distributions in winter and summer in the Gulf of California}

To obtain samples from the water column, typically from the surface to $200 \mathrm{~m}$ in January and July 2007, we used four manually operated opening-closing nets $(0.5 \mathrm{~m}$ mouth diameter, $300-\mu \mathrm{m}$ mesh). Sampling of strata was based on real-time echo-sounding measurements (Simrad EY-60, split beam, $120 \mathrm{kHz}$ ) of the depth to the densest sound-scattering layer (SSL) (Gómez-Gutiérrez and Robinson, 2006). We attempted to obtain one or two samples above the SSL, one in the densest part of the SSL, and one or two below the SSL, depending on the depth to the sea floor at the 
(A)

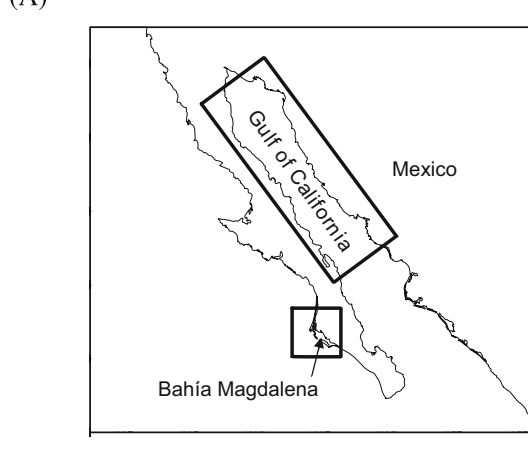

(B)

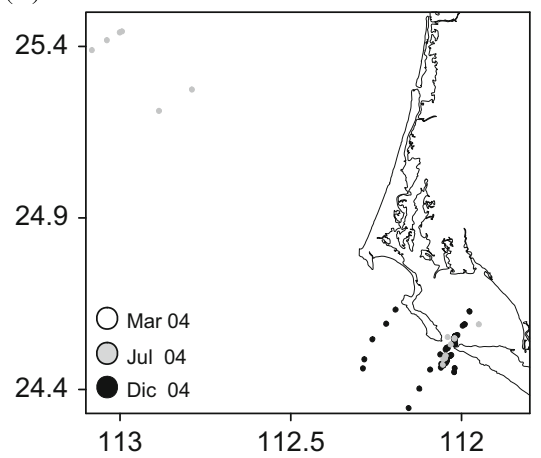

(C)

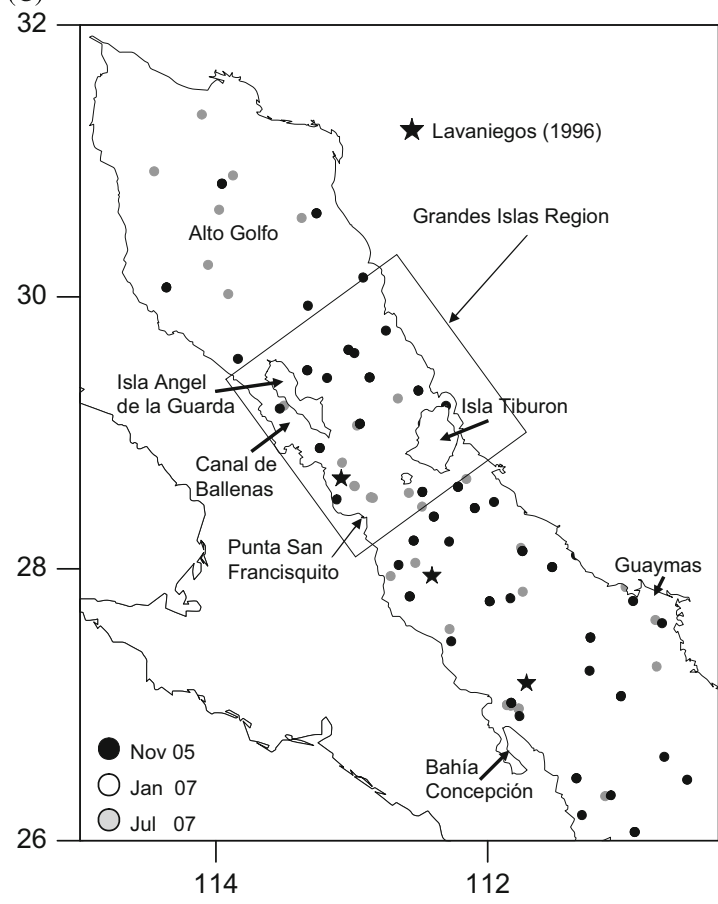

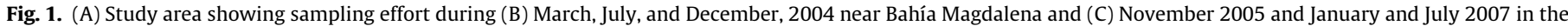
Gulf of California. The star symbols indicates the location of the stations where vertical movement of krill were previously studied (Lavaniegos, 1996).

station and local time to compare day and night vertical movements of the sex and developmental stage of the krill. Most of the samples were taken between $0-50,50-100,100-150$, and 150-200 m. Immediately after leaving each station, we towed a conical net $(300-\mu \mathrm{m}$ mesh, $0.5-\mathrm{m}$ mouth diameter) near the surface (usually between 1 and $2 \mathrm{~m}$ for $10 \mathrm{~min}$ at $6 \mathrm{~km} \mathrm{~h}^{-1}$ ) to collect neustonic $N$. simplex swarms. Immediately after retrieving each stratified and neustonic plankton net, the live juvenile and adult krill were sorted and counted aboard the research vessel with a stereoscope (Carl Zeiss SV11, 0.6-6.6 × ) to identify species, sex, and gonad development according to Ross et al. (1982). The length of the specimens was measured from the posterior edge of the eye to the tip of the telson.

Vertical profiles of temperature $\left({ }^{\circ} \mathrm{C}\right)$ and concentration of dissolved oxygen $\left(\mathrm{mg} \mathrm{O}_{2} \mathrm{l}^{-1}\right)$ were recorded at discrete depths $(0$, $5,10,25,50,75,100,150$, and $200 \mathrm{~m}$ ) with a calibrated sensor (YSI-1556) in January 2007 and continuous vertical records with a CTD sensor (Seabird 9) equipped with an oxygen meter in July 2007. At each station, at least four water samples were obtained (5-1 Niskin bottles) from the surface, 5, 10, 25, 50, 75, 100, and 150 or $200 \mathrm{~m}$. From each water sample, $350-500 \mathrm{ml}$ were filtered with $\mathrm{GF} / \mathrm{F}$ filters $(0.7-\mu \mathrm{m}$ pores) and the filters with samples immediately frozen in liquid nitrogen. Phytoplankton pigments were identified and quantified by HPLC with known standards for comparison (Vidussi et al., 1996). Main photosynthetic pigments were identified through retention times and spectral characteristics, and quantified using the pigment response factor (Mantoura and Repeta, 1997) obtained from commercial pigment standards (International Agency for ${ }^{14} \mathrm{C}$ determinations, Denmark). Here we report only the concentration of chlorophyll $a$ as a proxy for total phytoplankton biomass. The average and standard error of the abundance of krill and standard deviation of each environmental variable at each strata was calculated and plotted as a function of depth.

\subsection{Collection of live krill and incubation of females to estimate brood size and reproductive effort}

Swarms of krill were sampled during the day or night using a live net ( $1 \mathrm{~m}$ diameter, $5 \mathrm{~m}$ long, $300-\mu \mathrm{m}$ black mesh). The cod end was constructed of gray PVC and had a 0.215-m diameter and 0.70-m length (General Oceanic). This net was equipped with an underwater lamp (Ikelite Pro-Video Lite II system, $50 \mathrm{~W}$ ) to attract krill. On several occasions, a submarine video camera was attached to the net ring. In all cases, we sampled at the depth where the echo sounder (Simrad EY-60) indicated a dense SSL; the ship was allowed to drift to avoid damage to the krill during collection. On several occasions when the krill were abundant and healthy in appearance, additional live animals were incubated from samples from the standard oblique bongo net tows (depth $<230 \mathrm{~m})$ or Isaacs-Kidd midwater tows $(2 \times 2$-m mouth, Kalhsico, depth $<100 \mathrm{~m}$ ). Catches of zooplankton were diluted in $40-\mathrm{L}$ coolers filled with surface seawater from the sampled station. On all cruises, incubation of krill was set up in a cold room $\left(16 \pm 1{ }^{\circ} \mathrm{C}\right.$ under dark conditions) within a few minutes after collection. Female krill that were ready to spawn (gravid) were easily recognized by the distinct pink color of their ovaries under the pericardial area of the cephalothorax (Gómez-Gutiérrez and Robinson, 2005). To set up an incubation experiment, females were gently removed from the diluted plankton sample and each individual was placed in a 1-l bottle filled with filtered $(200 \mu \mathrm{m})$ surface seawater. From 10 to 50 females collected at each station were incubated. Most incubations lasted $48 \mathrm{~h}$ and all bottles were examined about every $12 \mathrm{~h}$ to detect molting, ovigerous females, and dead specimens. If ovigerous sac females were present or a specimen molted, they were usually preserved in $96 \%$ ethanol for later measurement of total length, brood size, and embryo diameter ( $>10$ embryos). Most live specimens were photographed (Olympus Camedia-2030, 3.3 megapixel resolution) to 
record sex, stage of female gonad development according to external morphology (Ross et al., 1982), and, in ovigerous females, identify the embryonic stage (Gómez-Gutiérrez and Robinson, 2005).

To calculate the proportion of carbon that each female produced as eggs, we estimated the female weight-specific carbon produced per female per spawning from the average carbon weight of the length-weight relationship for $N$. simplex. Dry weight $(D W)$ was expressed as mg dry weight per unit of total length $(T L)$ in $\mathrm{mm}$ (Gómez-Gutiérrez et al., 1996): $D W=0.005371 \times(T L)^{2.316}$.

The average carbon content of $N$. simplex embryos (multiplecell stage) was estimated using the $E$. pacifica proportion of carbon per embryo volume $\left(0.14 \times 10^{-6} \mu \mathrm{g} \mathrm{C} \mu \mathrm{m}^{-3} \mathrm{egg}^{-1}\right)$ as described by Gómez-Gutiérrez et al. (2007), hereafter referred to as egg carbon density $\left(C_{e}\right)$. We calculated the average $N$. simplex $C_{e}$ using an average embryo diameter of $339 \mu \mathrm{m}$ (Gómez-Gutiérrez and Robinson, 2005). We used the multiple-cell stage diameter because single cell embryos of $N$. simplex always have elliptical shape. Reproductive effort $(R)$, defined here as the percentage of carbon weight expended per female per spawning, was estimated as:

$\mathrm{R}=\left[\left(W_{e} \times B S\right) / W_{f}\right] \times 100$

where $W_{e}$ is the average egg carbon weight $\left(\mathrm{mgC} \mathrm{egg}^{-1}\right)$ estimated from the embryo volume and the krill $C_{e}, B S$ is the brood size measured as number of eggs per spawning (eggs brood $^{-1}$ female $^{-1}$ ), and $W_{f}$ is the female carbon weight (mg C female ${ }^{-1}$ ) assumed to be $40 \%$ of a female's DW (GómezGutiérrez et al., 2007).

\section{Results}

\subsection{Horizontal distribution of temperature and N. simplex with emphasis on ovigerous females}

In winter (January 2007), temperature at a depth of $4 \mathrm{~m}$ was $<19{ }^{\circ} \mathrm{C}$ (average $17{ }^{\circ} \mathrm{C}$ ) with a cold region $\left(14^{\circ} \mathrm{C}\right.$ ) north and south of the large island area $\left(\sim 29^{\circ} \mathrm{N}\right)$ (Fig. $\left.2 \mathrm{~A}\right)$. In summer (July 2007), temperatures increased about $10^{\circ} \mathrm{C}$ (average $27^{\circ} \mathrm{C}$ ) at a depth of $4 \mathrm{~m}$ (range from 28 to $32{ }^{\circ} \mathrm{C}$ ) in the upper gulf area north of the large islands (Fig. 2B).

During January, juvenile and adult $N$. simplex had higher densities throughout most of the gulf, particularly at areas with low temperatures $\left(<16{ }^{\circ} \mathrm{C}\right)$. Their lowest densities were in the eastern part of the gulf (Fig. 2C). During July, abundance of adults declined to low levels, with only a few stations having relatively high densities, and these were limited to the peninsular coast $\left(<27{ }^{\circ} \mathrm{C}\right)$. N. simplex were absent, except at Guaymas, along the mainland coast $\left(>29^{\circ} \mathrm{C}\right.$ ) (Fig. 2D). However, overall average abundance of juveniles and adults (pooling all samples) was significantly different between winter ( 889 ind. $1000 \mathrm{~m}^{-3}$ ) and summer ( 401 ind. $1000 \mathrm{~m}^{-3}$ ), having also a re-distribution of the $N$. simplex population between seasons.

Spawning areas in the gulf, indicated by the relative abundance of ovigerous females, showed distinct seasonal patterns. In winter $\left(14-19{ }^{\circ} \mathrm{C}\right)$, about $75 \%$ of the females spawned in three areas (south of Isla Angel de la Guarda, south of Isla Tiburon, and near Guaymas) with cold water $\left(<16{ }^{\circ} \mathrm{C}\right.$ ) (Fig. 2E). Hence, $\sim 50 \%$ of the spawning took place along the mainland coast. In summer $\left(25-31{ }^{\circ} \mathrm{C}\right)$, most spawning centered along the peninsular coast (16-19\%), areas with relatively low temperatures $\left(25-27{ }^{\circ} \mathrm{C}\right)$, except one station located at Guaymas with $29{ }^{\circ} \mathrm{C}$ (Fig. 2F).

\subsection{Vertical distribution of environmental conditions and N. simplex} with emphasis on ovigerous females

Contrasts between winter and summer in the gulf were indicated by the differences in temperature, dissolved oxygen, oxygen saturation, and chlorophyll $a$ in the vertical profiles (Fig. 3A-C). Winter temperatures were relatively homogeneous (well-mixed) throughout the water column, ranging between $16.4{ }^{\circ} \mathrm{C}$ at the surface to $13.5^{\circ} \mathrm{C}$ at $200 \mathrm{~m}$ (SD ranged from $\pm 0.6-0.9$ ). Summer temperatures increased considerably and the water column had a pronounced thermocline starting at a depth of $10-25 \mathrm{~m}$, with average SST of $27.4 \pm 1.5{ }^{\circ} \mathrm{C}$ and $13.7 \pm 0.6^{\circ} \mathrm{C}$ at $200 \mathrm{~m}$ (Fig. 3A). Year-round temperatures were similar at depths $>75 \mathrm{~m}$ (Fig. 3A). Dissolved oxygen was lower in the summer $\left(5.25 \pm 0.76-1.39 \pm 0.7 \mathrm{mg} \mathrm{l}^{-1}\right)$ than in winter $(5.85 \pm$ $\left.0.98-2.13 \pm 0.65 \mathrm{mg} \mathrm{l}^{-1}\right)$. The summer oxycline was considerably shallower (25-50 m) than in winter (75-100 m). The low-oxygen layer, on average, was significantly closer to the surface in summer $(90 \mathrm{~m})$ than in winter $(150 \mathrm{~m})$ season (Mann-Whitney test, $P<0.05$ ) (Fig. 3B). Maximum concentrations of chlorophyll $a$ occurred at $\sim 25 \mathrm{~m}$ during summer and at $\sim 50 \mathrm{~m}$ during winter, but were of similar magnitude in both seasons (Fig. 3C).

In the gulf, juveniles and adults were more abundant during the winter than in the summer season. The vertical distribution in both seasonal cruises showed that most krill occupy the top $150 \mathrm{~m}$ and were absent at $200 \mathrm{~m}$ day and night (Fig. 4A-H). Populations occupied the water column above the low-oxygen layer ( $<1.5 \mathrm{mg} \mathrm{O}_{2} \mathrm{l}^{-1}$ ), which on average was at $150 \mathrm{~m}$ during winter and $90 \mathrm{~m}$ during summer. However, in summer, krill was limited to the layer below the high temperature of the top $50 \mathrm{~m}$ (above the seasonal thermocline). In winter's well mixed conditions, juveniles were very abundant in the first $25 \mathrm{~m}$ independent of the time of sampling (Fig. 4A). Non-ovigerous females, ovigerous females, and males showed vertical movement, close to the surface at night and more abundant at $150 \mathrm{~m}$ during the day (Fig. 4B-D). Also, females were frequently forming daily surface swarms in winter (Fig. 4B, C).

During the summer with its shallow thermocline and lower dissolved oxygen in the first $50 \mathrm{~m}$, all stages of krill were present in low densities in the first $50 \mathrm{~m}$, with most of the population between 50 and $150 \mathrm{~m}$, a narrower vertical range than in winter (Fig. 4E-H). Ovigerous females were consistently found between 50 and $100 \mathrm{~m}$, without a day/night shift in movement during the summer (Fig. 4G).

The reproductive part of the population (ovigerous females and males with spermatophores) was concentrated at lower depths in summer (50-150 m) than in winter (surface to $100 \mathrm{~m}$ ), probably avoiding temperatures $>20^{\circ} \mathrm{C}$, which is known as an unfavorable conditions for embryonic development and growth of young larvae.

\subsection{Female brood size and reproductive effort}

$N$. simplex showed a statistically significant linear association between female brood size and female total length in and near Bahía Magdalena (Fig. 5A) and in the Gulf of California (Fig. 5B). Total length explains between $16 \%$ in the gulf and $23 \%$ in the bay of total brood size variability. There were seasonal differences in the slope of this relationship in both regions. In Bahía Magdalena, brood sizes were similar in March and July 2004, but very small brood sizes were observed in December (Fig. 5A). In the gulf, larger brood sizes were recorded during the warm-to-cold transition of November 2005 and summer of July 2007 than during the winter of January 2007 (Fig. 5B). Each side of the Baja California Peninsula appears to have a distinct seasonal reproduction pattern. 
(A)

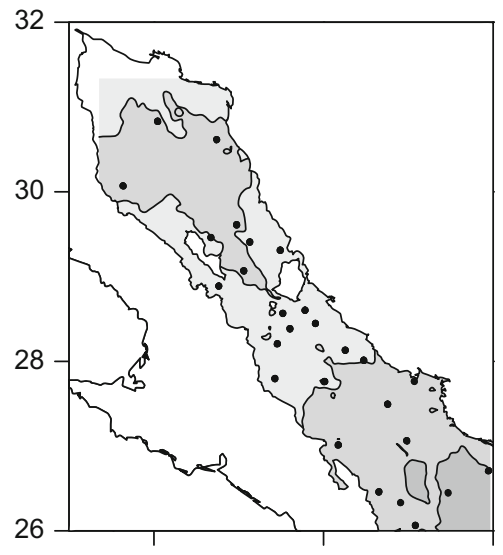

(C)

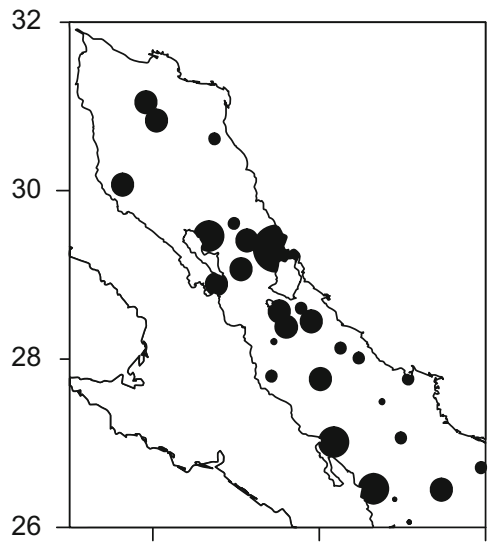

(E)

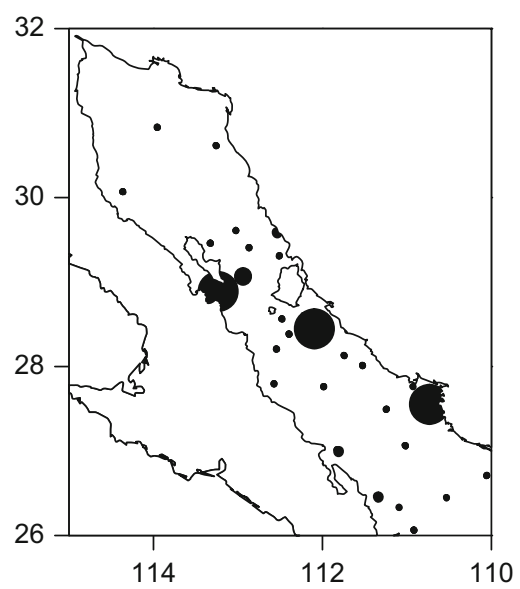

(B)

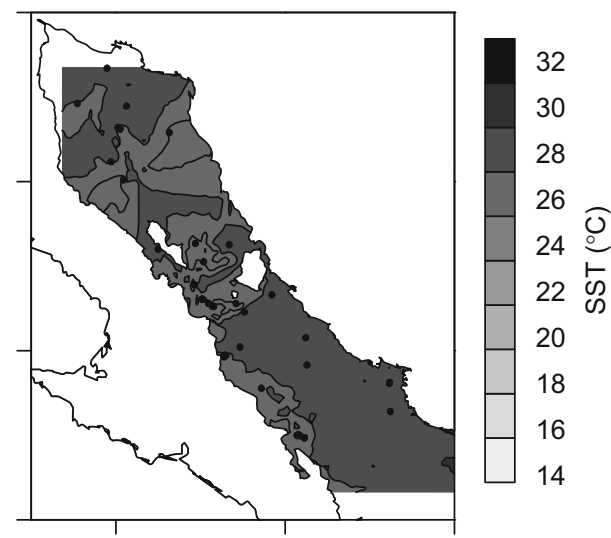

(D)

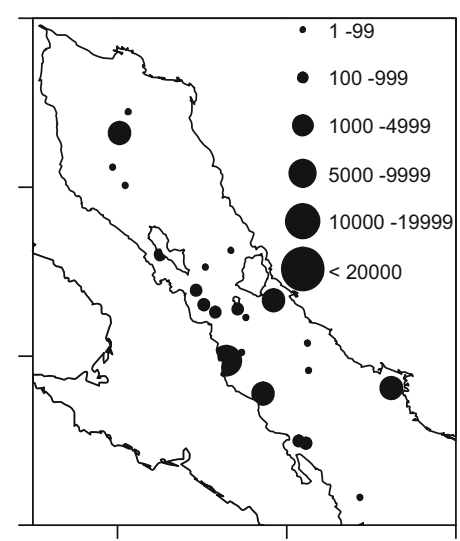

(F)

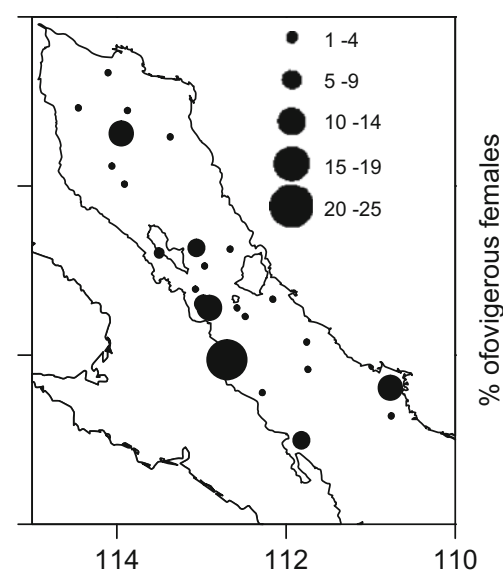

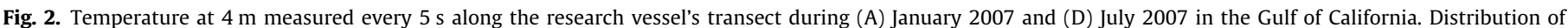

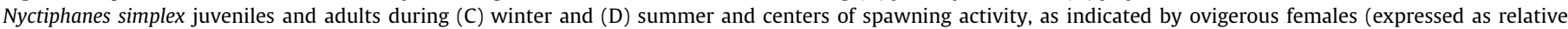
abundance during (E) winter and (F) summer.

On average, females spent about $8.4 \%$ of their carbon weight per spawning $\left(S_{x}=0.29, n=235\right)$, although virtually all populations spend $<8.4 \%$ of their weight in the production of one ovigerous sac (Fig. 5C, D). Only one female (10.19 mm total length, carbon weight $1.16 \mathrm{mg} \mathrm{C}_{\text {ind. }}^{-1}$ ) in the gulf (not shown in Fig. 5C) had a reproductive effort of $27.9 \%$, producing the maximum brood size recorded (116 eggs in both ovigerous sacs). There was no significant association of reproductive effort as a function of female carbon weight $\left(r^{2}=<0.003, P>0.05\right)$ (Fig. 5C, D) or female total length $\left(r^{2}=<0.005, P>0.05\right)$, which indicates that reproductive effort of females vary, independent of size and weight, but most likely influenced by local food quality and quantity. Reproductive effort in
December 2004 was below the average in Bahía Magdalena and, in November-December 2005, all brood sizes were above the average brood size recorded in the gulf (Fig. 5C, D).

\section{Discussion}

\subsection{Horizontal and vertical distribution of Nyctiphanes simplex in} the Gulf of California

Horizontal distribution of ovigerous females clearly showed seasonal differences, mostly aggregating along the northeastern 
(A)
Temperature

$\left({ }^{\circ} \mathrm{C}\right)$

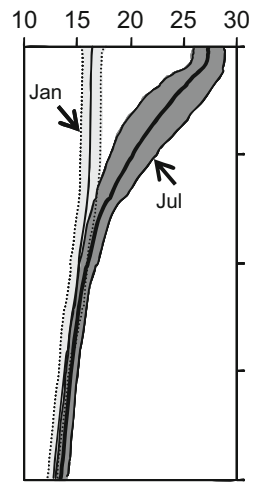

(B)

Oxygen saturation (\%)

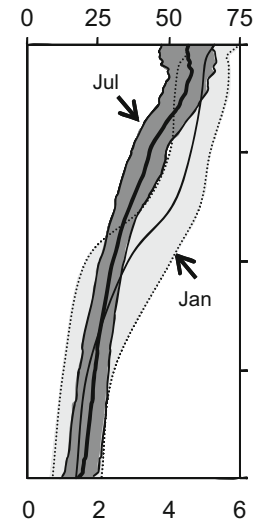

Oxygen concentration (mg L-1)
(C)

Chlorophyll a $\left(\mathrm{mg} \mathrm{L}^{-1}\right.$ )

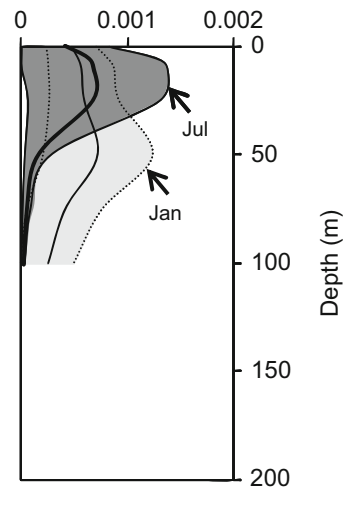

Fig. 3. Mean and standard deviation vertical profile of (A) temperature $\left({ }^{\circ} \mathrm{C}\right)$, (B) percentage of oxygen saturation (\%) and oxygen concentration $\left(\mathrm{mg} \mathrm{l}^{-1}\right)$, and (C) chlorophyll- $a$ concentration (HPLC) measured in the cold (January, light gray thin line; $n=32$ stations) and warm (July, dark gray bold line; $n=49$ stations) seasons.

side of the gulf in winter and along the western side during the summer, usually in areas with lower temperatures. This pattern is related to upwelling induced by prevailing winds dominating the mainland coast in winter and the peninsular coast in summer (Badan-Dangon et al., 1985; Pegau et al., 2002; Jiménez et al., 2005). However, we always found reproductive females in both seasons south of the large islands and the wide channel between Isla Angel de la Guarda and the Baja California Peninsula (Fig. 1C). These areas are usually the coldest part of the gulf, primarily caused by inflow of deep water over sills at both sides of the Canal de Ballenas. This convergence at depth leads to divergence in the upper waters and to surface outflow through both ends. Deep inflow is more intense during winter than summer (López et al., 2006; Marinone, 2007). According to previous studies, abundance of adults and juveniles tend to significantly decrease with the shift from winter to summer (Brinton and Townsend, 1980; Gendron, 1992; Lavaniegos et al., 1989). We detected significant differences in average abundance between the seasons, but a more homogeneously distributed population in winter and a more aggregated distribution in summer. This suggests that during the summer populations re-distributed and concentrated in several cold refuge areas along the peninsular coast of the gulf.

$N$. simplex displays a highly dynamic daily vertical movement, but also frequently forms daytime surface swarms (Gendron, 1992) or dense aggregations over the continental shelf in the Pacific, while interacting with the epibenthic habitat (GómezGutiérrez and Robinson, 2006; Robinson and Gómez-Gutiérrez, 1998). In general terms, $N$. simplex is considered a short-distance migratory species that occupies shallow waters during the night and deeper waters during the day $(<280 \mathrm{~m}$ ) (Brinton, 1962, 1967, 1979; Lavaniegos, 1996). In the gulf, Brinton (1979) investigated the vertical distribution of euphausiids collected from six opening-closing bongo net tows at three stations (day and night at the same station) collected in May and June 1974 at the mouth of the gulf and Lavaniegos (1996) analyzed samples from three stations collected in May 1965 along the peninsular coast in the central part of the gulf. Here, we contrast the winter and summer vertical movement in 2007 over an extensive latitudinal range in the gulf (Fig. 1C).
In January 2007, the depth where krill were collected was greater than previously reported for the gulf (Brinton, 1979; Lavaniegos, 1996). We demonstrated that juveniles and adults in the gulf have distinct vertical behavior, always located above $150 \mathrm{~m}$ to avoid the low-oxygen layer. $N$. simplex migrates close to the surface in winter when the water column is homogeneously cold $\left(<17^{\circ} \mathrm{C}\right)$ and congregates in considerably deeper waters in summer, when the temperature was warm $\left(22-32{ }^{\circ} \mathrm{C}\right)$ in the upper $50 \mathrm{~m}$. The reproductive population (pink-colored gonad in females, ovigerous females, and males with spermatophores) avoid the warm nearsurface layer day and night, a response that supports favorable embryonic development (Gómez-Gutiérrez and Robinson, 2005) and larval development (Gómez-Gutiérrez, 1996). Thus, in the summer, vertical movement is restricted by a seasonal thermocline within the first $50 \mathrm{~m}$ and a shallower low oxygen layer at $\sim 90 \mathrm{~m}$. A similar change in vertical movement was observed in Euphausia pacifica populations near northeastern Japan, where this species avoided near-surface waters when temperature were high (Endo and Yamano, 2006; Iguchi et al., 1993).

Gendron (1992) reported that $N$. simplex usually form reproductive swarms at the surface in spring (March-April) southwest of the Gulf $\left(24-26^{\circ} \mathrm{N}\right)$, but at Ballenas Channel $\left(29^{\circ} \mathrm{N}\right)$, the year-round colder region of the gulf, $N$. simplex form surface swarms from March to early August, being almost absent from October to November (Ladrón de Guevara et al., 2008). We confirmed these observations, accounting for these events to times when the water was cold and the mixed layer was thick, as occurred during January 2007. Previous to our study, Lavaniegos (1996) conducted the only study of daily vertical movement of krill in the central part of the gulf. From samples collected in June 1961 at Punta Eugenia $\left(\sim 27^{\circ} 50^{\prime} \mathrm{N}, 115^{\circ} 05^{\prime} \mathrm{W}\right)$ on the Pacific side of the peninsula ( $n=3$ stations) and in May 1965 in the gulf ( $n=3$ stations) and described $N$. simplex as a species migrating throughout the thermocline with most of the population congregating to depths of up to $100 \mathrm{~m}$. She concluded that in such regions, oxygen depletion in the gulf was not restrictive for vertical movement of the dominant temperate species ( $N$. simplex and Nematoscelis difficilis); however, the low-oxygen layer was not recorded. Brinton (1979) recognized that hypoxic $\left(<1.5 \mathrm{ml} \mathrm{O}_{2}\right.$ $\left.1^{-1}\right)$ or anoxic $\left(<0.5 \mathrm{ml} \mathrm{O}_{2} \mathrm{l}^{-1}\right)$ conditions in the Eastern Tropical Pacific was restrictive for $N$. simplex. Färber-Lorda et al. (1994, 2004) reported that no $N$. simplex was collected south of the Gulf of Tehuantepec $\left(14-16^{\circ} \mathrm{N}\right)$, where E. lamelligera is the dominant euphausiid throughout the year and where the low oxygen layer is usually very shallow ( $<60 \mathrm{~m}$ ) (Fiedler and Talley, 2006).

Our results show that juveniles and immature $N$. simplex occur above and below the thermocline in the summer, but the reproductive portion of the population (particularly ovigerous females and males with spermatophores) actively avoid warm strata in summer. In both seasons, adults are found above the low-oxygen layer, confirming that this oceanographic feature is a significant limiting factor. Tremblay (2008) reported significantly higher antioxidant enzymes (up to 30 times; mostly superoxide dismutase), and higher oxidative damages (up to 100 times and high lipid peroxidation) in summer than in winter and also reported on the level that has lethal consequences $(<3.5 \mathrm{ml}$ $\mathrm{O}_{2} \mathrm{l}^{-1}$ ). These sensitive indicators easily explain why $N$. simplex avoids waters with low oxygen levels (Tremblay, 2008).

Warm water in July 2007 had consistently lower fluorescence values than in cold water in January, an unfavorable condition for the first-feeding larval stage (Calyptopis 1). However, the peninsular coast of the gulf had higher fluorescence values (continuous at 4-m depth records) in July compared to values found in January 2007 (data not shown), but adults were not present in this relatively warm layer in this area. We concluded that avoidance of warmer waters, horizontally and vertically is a response to increased 


\section{Sampling}

January
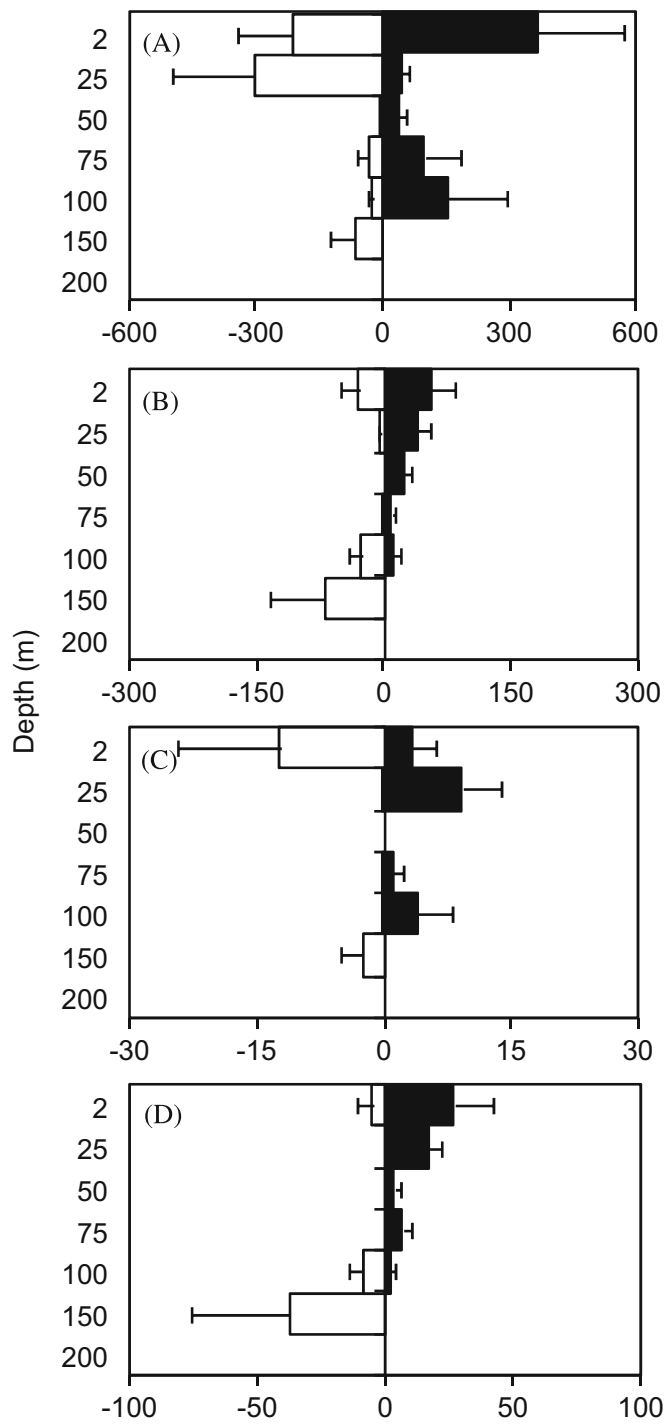

July-August
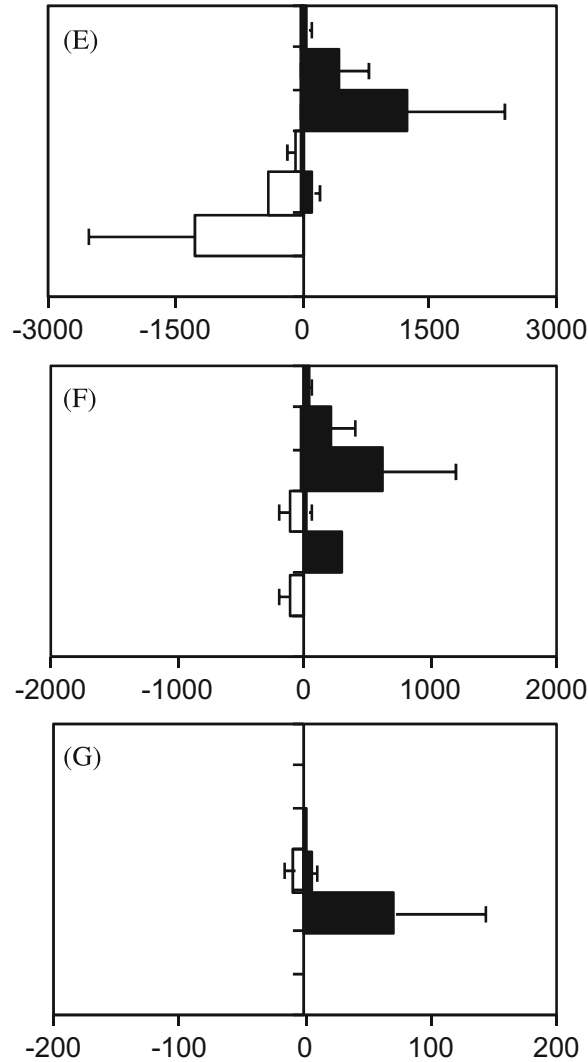

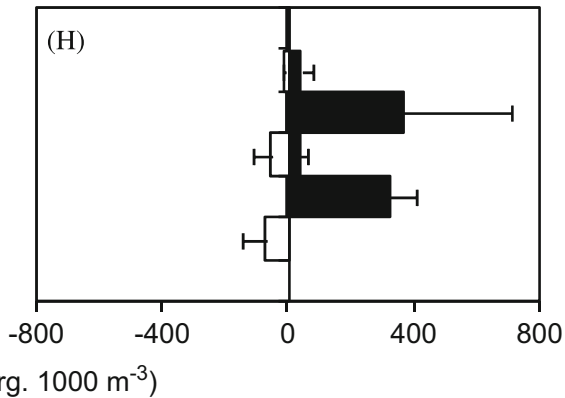

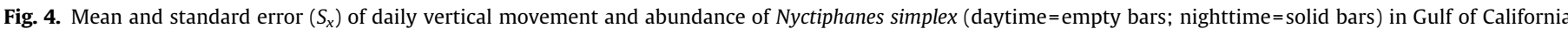

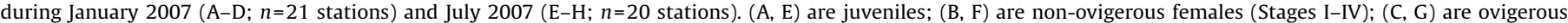
females; and $(D, H)$ are males with spermatophores.

temperature that are controlled by physiologic capabilities to face hypoxic conditions and not necessarily to obtain a reduced amount of available food in the epipelagic zone. This explains why this species cannot penetrate the lower latitude parts of the Eastern Tropical Pacific where the low-oxygen layer is closer to the surface and is warm. Generally, the distribution of $N$. simplex seems to be limited by higher temperatures and low oxygen levels.

\subsection{Seasonal variability of brood size and reproductive effort}

In Bahía Magdalena, brood sizes were similar in March and July 2004, but very small in December 2004, indicating that most of the reproduction of this species was restricted to spring and summer when the California Current is intense. The small broods in December occurred when equatorial water $\left(>23{ }^{\circ} \mathrm{C}\right.$ and low concentrations of chlorophyll $a$ ) occupied the southwestern coast of the Baja California Peninsula causing a reduction in population abundance and body growth rates (Gómez-Gutiérrez, 1995, 1996; Gómez-Gutiérrez et al., 1996). Low abundance and small brood size were not an artifact of zooplankton sampling because sampling effort was similar to the previous two cruises. In the gulf, we expected larger brood sizes in January 2007 than during the rest of the year, but larger brood sizes were recorded during the warm-to-cold transition (November 2005) and the summer (July 2007). Our interpretation of this is that warm water with high chlorophyll $a$ (phytoplankton) enable females to grow faster, mature earlier, and produce larger broods than in the cold season (gonad development inversely associated with temperature) (Gómez-Gutiérrez et al., 2010). Each side of the Baja California Peninsula seems to have seasonal reproduction patterns that are related to the distinct seasonal variability in the environment and the current systems. In Bahía Magdalena, the thermocline is relatively deep $(40-60 \mathrm{~m})$, with a thick well mixed warm $\left(>23{ }^{\circ} \mathrm{C}\right.$ ) water above the thermocline during winter (December). Concentrations of chlorophyll are usually very low (data not 

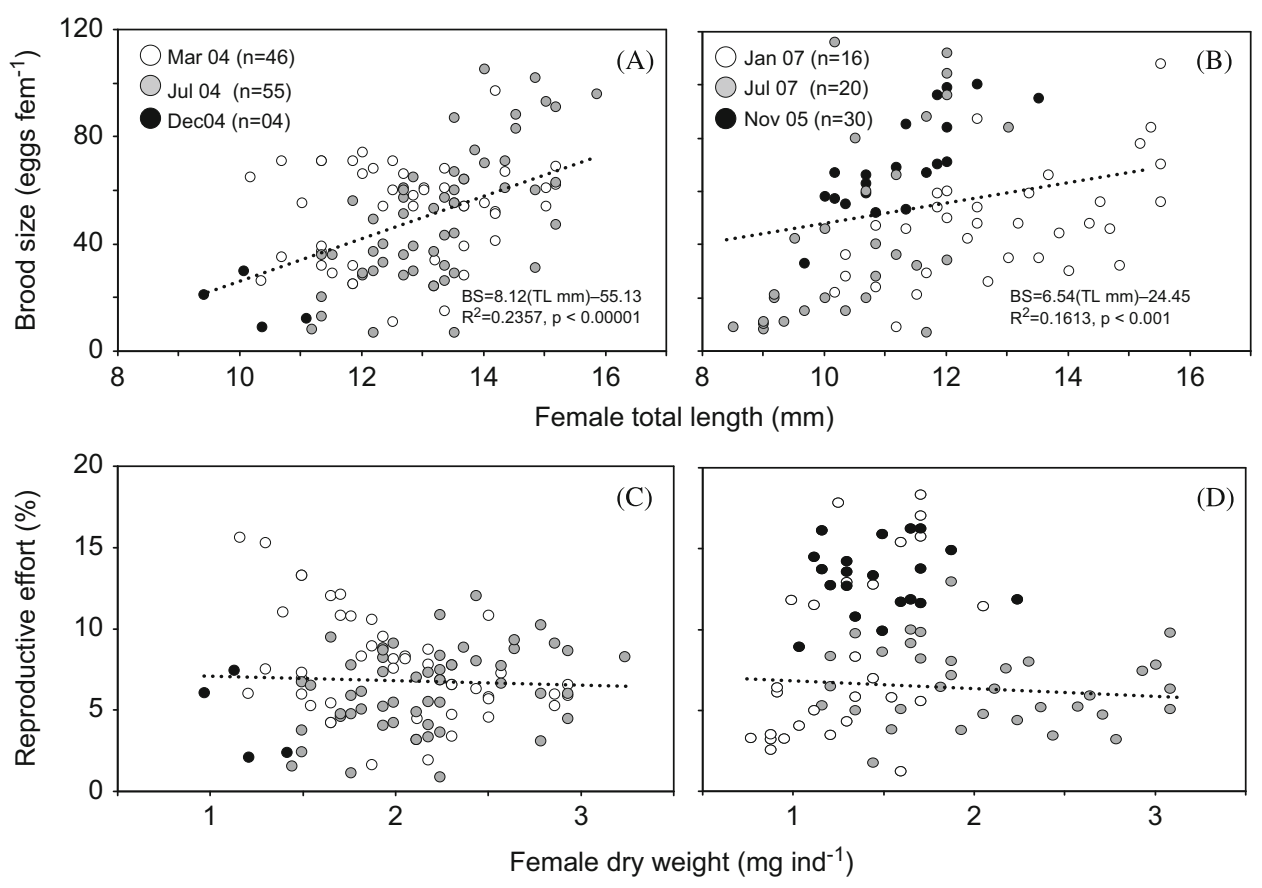

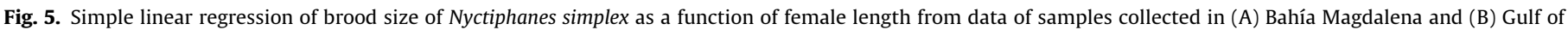

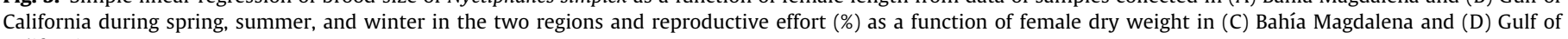
California.

shown). In the gulf during winter (January), the water is typically cold $\left(<18{ }^{\circ} \mathrm{C}\right)$ and concentrations of chlorophyll were about the same as in summer, hence supporting comparatively larger broods and covering larger spawning areas than in Bahía Magdalena.

Contrary to expectations, the warm-cold transition in the gulf seems to be, on average, the period with larger broods and reproductive effort values in comparison to winter and summer. This pattern does not match the trend of reduction of abundance of $N$. simplex populations observed by others (Brinton and Townsend, 1980; Gendron, 1992). In general, broods were larger in the gulf than in the area of Bahía Magdalena (this study). However, in the vicinity of Bahía Magdalena $\left(24-25^{\circ} \mathrm{N}\right)$, estimates of body growth secondary productivity for $N$. simplex was about half the level observed at Punta Abreojos $\left(24^{\circ} 45^{\prime} \mathrm{N}\right)$ and north of Punta Eugenia $\left(28^{\circ} \mathrm{N}\right)$, which appears to be a latitudinal cline (De Silva-Dávila et al., 2002; Gómez-Gutiérrez et al., 1996; Lavaniegos, 1995). This implies that $N$. simplex along the Pacific coast of the peninsula are related to temperatures of the currents. Broods on this coast are not categorically smaller than broods in the gulf.

The length of fertile females explains $16-23 \%$ of the variability in brood size, which is a relatively significant relationship, compared with temperate broadcast-spawners, such as Euphausia pacifica and Thysanoessa spinifera of similar length $(<14 \%$ variability), The size of the brood of these two broadcastspawners tends to be smaller for the larger females in a population following a bell-shaped curve (Feinberg et al., 2007; Gómez-Gutiérrez et al., 2006, 2007; Iguchi and Ikeda, 1994; Pinchuk and Hopcroft, 2006; Ross et al., 1982). In our study, $N$. simplex broods at Bahía Magdalena and in the gulf were considerably larger at 5-116 embryos female ${ }^{-1}$ ( $n=237$ females). In contrast, Gendron (1992) reported 18-70 embryos female ${ }^{-1}$ ( $n=71$ females) in the gulf and Lavaniegos (1995) reported 32-70 embryos female ${ }^{-1} \quad(n=17$ females $)$ at Bahía Sebastian Vizcaíno $\left(28^{\circ} \mathrm{N}\right)$ on the Pacific side of the peninsula. Thus, egg production of $N$. simplex may be larger than previously estimated.
Lavaniegos (1995) assumed that the dry weight of one $N$. simplex egg was $8.1 \mu \mathrm{g}$, based on a report on Nyctiphanes australis by Hosie and Ritz (1983). Assuming 40\% carbon content of the dry weight, Lavaniegos' average egg carbon content would be $3.4 \mu \mathrm{g} \mathrm{C} \mathrm{egg}^{-1}$, which is relatively close to our average estimate of $2.79 \mu \mathrm{g} \mathrm{C} \mathrm{egg}{ }^{-1}$. While the estimate of average egg weight may be acceptable in estimating egg production per brood, it probably underestimates reproduction since he assumed an interbrood period of 30 days and maximum brood size recorded was almost $40 \%$ less than the largest brood reported in our study.

The smallest ovigerous female specimen we observed was $7.5 \mathrm{~mm}$ (about 52 days old, with 5 eggs) and the largest was $15.9 \mathrm{~mm}$ (this study and Gómez-Gutiérrez, 1995). Using a von Bertalanffy growth model (Lavaniegos, 1992), the estimated duration of the adult phase would last 6-7 months (neglecting a shrinkage process). This life span is similar to the estimated adult life-span of Nyctiphanes capensis (Barange and Stuart, 1991). Considering an average brood size of 52 embryos female ${ }^{-1}$, an average interbrood period of 10 days, with a range 7-26 days (Zavala-Hernández, 2007; Gómez-Gutiérrez et al., 2010), and assuming an adult life span of 6 months (Lavaniegos, 1995); the average number of spawnings per female would be 18 with a range of 26-7, respectively), and the average total fecundity would be 936 eggs female ${ }^{-1}$ life span $^{-1} \quad$ (360-1337 eggs female $^{-1}$ life $\operatorname{span}^{-1}$ ). This is smaller than the life span fecundity estimated for E. pacifica (similar size) with a maximum of 8600 eggs per female under laboratory conditions (Feinberg et al., 2007). Brood size of N. simplex is slightly larger than Pseudeuphausia latifrons of similar size (83.1 $\pm 3.0 \mathrm{SE}, n=93)$ (Wilson et al., 2003). Brood size of $N$. difficilis, another sac-spawner that is abundant in the gulf, has considerably larger broods than $N$. simplex, ranging between 156-425 eggs (Nemoto et al., 1972; Gómez-Gutiérrez, 2003). However, since the interbrood period of $N$. difficilis has not been measured, it is not possible to estimate its egg production rate.

Brinton and Townsend (1980) reported that the reproduction of $N$. simplex in the gulf is from February to June (samples collected in 1957). We have evidence that reproductive activity, 
indicated by ovigerous females and calyptopis stages within the gulf occurred in January 2007 with relatively small broods, compared with July 2007 and the summer-winter transition (November-December 2005). In Bahía Magdalena, reproduction occurred at very low levels in December 2004, even when temperature increased considerably because the population had a very low proportion of ovigerous females and very small broods. This evidence indicate that $N$. simplex reproduces throughout the year, although year-round egg production may result from distinct cohorts, since the life span of this species is about 8 months (Lavaniegos, 1992, 1995).

\section{Conclusions}

We demonstrated that the distribution of $N$. simplex has a distinct seasonal vertical movement of the reproductive population, usually avoiding warm surface water $(<50 \mathrm{~m})$ during summer and cool, low-oxygen water ( $>90 \mathrm{~m}$ in summer and $>150 \mathrm{~m}$ in winter). In general, vertical movements are greater than previously observed in the Gulf of California. Fecundity of this sac-spawner is less than broadcast-spawners of similar size, which is partly related to the size of the female and its ovigerous sac (Feinberg et al., 2007; Gómez-Gutiérrez et al., 2006, 2007; Pinchuk and Hopcroft, 2006). Broods observed in this study were almost twice as large as estimates of previous studies (Gendron, 1992; Lavaniegos, 1995). We conclude that females invest a larger portion of their body weight $(<18 \%)$ to egg production (reproductive effort method) than previously thought, but it is proportionately less than reproductive effort (28.4\%) of $N$. difficilis (Nemoto et al., 1972) and broadcast-spawners of similar size, such as $E$. pacifica or $T$. spinifera that, on average, spend about $15-40 \%$ of their body weight on eggs (Gómez-Gutiérrez et al., 2007), or the even higher reproductive effort in polar species, such as Euphausia superba (Nicol et al., 1995; Ross and Quetin, 1983).

\section{Acknowledgments}

We thank N. Sánchez-Reyes, as part of the PIFI-IPN grant program and Karmina Arroyo-Ramirez for their valuable technical assistance with the DEPBAMA biological information. We thank the crew of the R/V 'El Puma' and graduate students and scientists from the Fisheries Ecology Laboratory (ICMyL-UNAM), UABCS, and CICIMAR for their cooperation in collecting acoustic and zooplankton samples. Ira Fogel at CIBNOR provided important editorial advice. J.G.G., C.J.R., and C.R.J. were supported by SNI fellowships; J.G.G. received COFAA-IPN and EDI-IPN grants, and N.T. and S.M.G. were supported by PIFI-IPN grants. This project was funded by Centro Interdisciplinario de Ciencias MarinasInstituto Politécnico Nacional (CGPI 20040013, 20050082, 20060856, 20070279, 20080490, and 20090090); by Consejo Nacional de Ciencia y Tecnología (CONACyT-FOSEMARNAT-200401-144, CONACyT-SAGARPA S007-2005-1-11717), and Instituto de Ciencias del Mar y Limnología of the Universidad Nacional Autónoma de México (PAPITT IN219502 and IN210622).

\section{References}

Badan-Dangon, A., Koblinsky, C.J., Baumtgartner, T., 1985. Spring and summer in the Gulf of California: observations of surface thermal patterns. Oceanological Acta $8,13-22$

Barange, M., Stuart, V., 1991. Distribution patterns, abundance and population dynamics of the euphausiids Nyctiphanes capensis and Euphausia hanseni in the northern Benguela upwelling system. Marine Biology 109, 93-101.

Brinton, E., 1962. The distribution of Pacific euphausiids. Bulletin of Scripps Institution Oceanography (University of California) 8, 51-270.
Brinton, E., 1967. Vertical migration and avoidance capability of euphausiids in the California Current. Limnology and Oceanography 12, 451-483.

Brinton, E., 1979. Parameters relating to the distributions of planktonic organisms, especially euphausiids in the eastern tropical Pacific. Progress in Oceanography 8, 125-189.

Brinton, E., Townsend, A.W., 1980. Euphausiids in the Gulf of California-the 1957 cruises. California Cooperative Oceanic Fishery Investigation Report 21 211-236

Brinton, E., Ohman, M.D., Townsend, A.W., Knight, M.D., Bridgeman, A.L., 2000. In: Euphausiids of the World Ocean. Expert Center for Taxonomic Identification, Amsterdam.

Brodeur, R.D., 1986. Northward displacement of the euphausiid Nyctiphanes simplex Hansen to Oregon and Washington waters following the El Niño event of 1982-83. Journal of Crustacean Biology 6, 686-692.

De Silva-Dávila, R., Palomares-García, R., 1998. Unusual larval growth production of Nyctiphanes simplex. Bahía de La Paz, Baja California, México. Journal of Crustacean Biology 18, 490-498.

De Silva-Dávila, R., Palomares-García, R., Martínez-López, A., Carballido-Carranza, A., 2002. Standing stock of Nyctiphanes simplex in the southern region of the California Current System. Journal of Plankton Research 24, 1057-1066.

Endo, Y., Yamano, F., 2006. Diel vertical migration of Euphausia pacifica (Crustacea, Euphausiacea) in relation to molt and reproductive processes, and feeding activity. Journal of Oceanography 62 (5), 693-703.

Färber-Lorda, J., Lavin, M.F., Zapatero, M.A., Robles, J.M., 1994. Distribution and abundance of euphausiids in the Gulf of Tehuantepec during wind forcing. Deep-Sea Research II 41, 359-367.

Färber-Lorda, J., Lavín, M.F., Zapatero, M.A., Robles, J.M., 2004. Effects of wind forcing on the trophic conditions, zooplankton biomass and krill biochemical composition in the Gulf of Tehuantepec. Deep-Sea Research II 51, 601-614.

Feinberg, L.R., Shaw, C.T., Peterson, W.T., 2007. Long-term laboratory observations of Euphausia pacifica fecundity: a comparison of two geographic regions. Marine Ecology Progress Series 341, 141-152.

Fiedler, P.C., Talley, L.D., 2006. Hydrography of the Eastern Tropical Pacific: a review. Progress in Oceanography 69, 143-180.

Gendron, D.L., 1992. Population structure of daytime surface swarms of Nyctiphanes simplex (Crustacea: Euphausiacea) in the Gulf of California, Mexico. Marine Ecology Progress Series 87, 1-6.

Gómez-Gutiérrez, J. 1995. Distribution patterns, abundance and population dynamics of the euphausiids Nyctiphanes simplex and Euphausia eximia in the west coast of Baja California, Mexico. Marine Ecology Progress Series 119 63-76

Gómez-Gutiérrez, J., 1996. Ecology of early larval development of Nyctiphanes simplex Hansen (Euphausiacea) off the southwest coast of Baja California Mexico. Bulletin of Marine Science 58, 131-146.

Gómez-Gutiérrez, J., 2003. Hatching mechanism and accelerated hatching of the eggs of a sac-spawning euphausiid Nematoscelis difficilis. Journal of Plankton Research 25, 1397-1411.

Gómez-Gutiérrez, J., Robinson, C.J., 2005. Embryonic, early larval development time, hatching mechanism and interbrood period of the sac-spawning euphausiid Nyctiphanes simplex Hansen. Journal of Plankton Research 27 279-295.

Gómez-Gutiérrez, J., Robinson, C.J., 2006. Tidal current transport of epibenthic swarms of the euphausiid Nyctiphanes simplex in a shallow subtropical bay in Baja California Sur, Mexico. Marine Ecology Progress Series 320, 215-231.

Gómez-Gutiérrez, J., De Silva-Dávila, R., Lavaniegos, E.B., 1996. Growth production of the euphausiid Nyctiphanes simplex at the coastal shelf off Magdalena Bay Baja California Sur, México. Marine Ecology Progress Series 138, 309-314.

Gómez-Gutiérrez, J., González-Chávez, G., Robinson, C.J., Arenas-Fuentes, V., 1999. Latitudinal changes of euphausiid assemblages related to dynamics of the scattering layer along Baja California, October 1994. Scientia Marina 63 (1), 79-91.

Gómez-Gutiérrez, J., Palomares-García, R., Gendron, D., 1995. Community structure of the euphausiids populations along the west coast of Baja California, México during the weak ENSO 1986-87. Marine Ecology Progress Series 120, 41-51.

Gómez-Gutiérrez, J., Feinberg, L.R., Shaw, C.T., Peterson, W.T., 2006. Variability in brood size and female length of Euphausia pacifica among three populations in the North Pacific. Marine Ecology Progress Series 323, 185-194.

Gómez-Gutiérrez, J., Feinberg, L.R., Shaw, C.T., Peterson, W.T., 2007. Interannua and geographical variability of the brood size of the euphausiids Euphausia pacifica and Thysanoessa spinifera along the Oregon coast (1999-2004). DeepSea Research Part I 54, 2145-2169, doi:10.1016/j.dsr.2007.09.003.

Gómez-Gutiérrez, J.,Rodríguez-Jaramillo, C., Del Ángel-Rodríguez, J., Robinson, C.J., Zavala-Hernández, C., Martínez-Gómez, S., Tremblay, N., 2010. Biology of the subtropical sac-spawning euphausiid Nyctiphanes simplex in the northwestern seas of Mexico: Interbrood period, gonad development and lipid content. Deep-Sea Research II 57 (7-8), 616-630.

Hidalgo-González, R.M., Alvarez-Borrego, S., 2000. Chlorophyll profiles and the water column structure in the Gulf of California. Oceanologica Acta 24, 19-28.

Hidalgo-González, R.M., Alvarez-Borrego, S., 2004. Total and new production in the Gulf of California estimated from ocean color data from the satellite sensor SeaWIFS. Deep-Sea Research II 51, 739-752.

Hosie, G.W., Ritz, D.A., 1983. Contribution of moulting and eggs to secondary production in Nyctiphanes australis (Crustacea: Euphausiacea). Marine Biology 77, 215-220. 
Iguchi, N., Ikeda, T., 1994. Experimental study on brood size, egg hatchability and early development time of the euphausiid Euphausia pacifica from Toyama Bay, Southern Japan. Sea Bulletin of Japan Sea National Fishery Research Institution 44, 49-57.

Iguchi, N., Ikeda, T., Imamura, A., 1993. Growth and life cycle of an euphausiid crustacean (Euphausia pacifica Hansen) in Toyama Bay, Southern Japan Sea. Sea Bulletin of Japan Sea National Fishery Research Institution 43, 69-81.

Jiménez, A., Marinone, S.G., Parés-Sierra, A., 2005. Effect of the spatial and temporal variability of winds on the circulation in the Gulf of California. Ciencias Marinas 31, 357-368.

Ladrón de Guevara, P., Lavaniegos, B.E., Heckel, G., 2008. Fin whales (Balaenoptera physalus) foraging on daytime surface swarms of the euphausiid Nyctiphanes simplex in Ballenas Channel, Gulf of California, Mexico. Journal of Mammalogy 89, 559-566.

Lavaniegos, B.E., 1987. Efectos del evento de El Niño 1982-1983 sobre las poblaciones de eufaúsidos del Golfo de California. Master's Thesis, Centro de Investigaciones Científicas y de Educación Superior de Ensenada, Mexico, $113 \mathrm{pp}$.

Lavaniegos, B.E., 1988. Biomasa y composición de los grupos principales del zooplancton del Golfo de California durante la fase de relajamiento del evento de "El Niño" en 1984. Bachaelor Thesis, Facultad de Ciencias, Universidad Nacional Autónoma de México, 78 pp.

Lavaniegos, B.E., 1992. Growth and larval development of Nyctiphanes simplex in laboratory conditions. California Cooperative Oceanic Fishery Investigation Report 33, 162-171.

Lavaniegos, B.E., 1995. Production of the euphausiid Nyctiphanes simplex in Vizcaíno Bay, western Baja California. Journal of Crustacean Biology 15 444-453

Lavaniegos, B.E., 1996. Vertical distribution of euphausiid life stages in waters adjacent to Baja California. Fishery Bulletin 94, 300-312.

Lavaniegos, B.E., Lara-Lara, J.R., Brinton, E., 1989. Effects of the 1982-83 El Niño event on the euphausiid populations of the Gulf of California. California Cooperative Oceanic Fisheries Investigation Reports 30, 73-87.

López, M., Candela, J., Argote, M.L., 2006. Why does the Ballenas Channel have the coldest SST in the Gulf of California? Geophysical Research Letters 33, L11603, doi:10.1029/2006GL015908.

Mantoura, R.F.C., Repeta, D., 1997. Calibration methods for HPLC. In: Jeffrey, S.W., Mantoura, R.F.C., Wright, S.W. (Eds.), Phytoplankton Pigments in Oceanography: Guidelines to Modern Methods.. UNESCO Publ., Paris, pp. 407-428.

Marinone, S.G., 2007. Why does the Ballenas Channel have the coldest SST in the Gulf of California? Geophysical Research Letters 34, L02607, doi:10.1029/ 2006GL0285589.
Nemoto, T., Kamada, K., Hara, K., 1972. Fecundity of a euphausiid crustacean, Nematoscelis difficilis, in the North Pacific Ocean. Marine Biology 14, 41-47.

Nicol, S., De La Mare, W.K., Stolp, M., 1995. The energetic cost of egg production in Antarctic krill (Euphausia superba Dana). Antarctic Science 7, 25-30.

Pegau, W.S., Boss, E., Martínez-Alcalá, A., 2002. Ocean color observation of eddies during the summer in the Gulf of California. Geophysical Research Letters 29, $1-3$.

Pinchuk, A.I., Hopcroft, R.R., 2006. Egg production and early development of Thysanoessa inermis and Euphausia pacifica (Crustacea: Euphausiacea) in the northern Gulf of Alaska. Journal of Experimental Marine Biology and Ecology 332, 206-215.

Robinson, C.J., Gómez-Gutiérrez, J., 1998. Daily vertical migration of dense scattering layers related to shelf-break area in the northwest coast of Baja California, Mexico. Journal of Plankton Research 20, 1679-1697.

Ross, M., Quetin, L.B., 1983. Spawning frequency and fecundity of the Antarctic krill Euphausia superba. Marine Biology 77, 201-205.

Ross, R.M., Daly, K.L., English, T.S., 1982. Reproductive cycle and fecundity of Euphausia pacifica in Puget Sound, Washington. Limnology and Oceanography 27, 304-314.

Smith, P.E., Richardson, S., 1979. Técnicas modelo para prospecciones de huevos y larvas de peces pelágicos. F.A.O. Documento Tecnico de Pesca 175 $1-107$.

Tanasichuk, R.W., Cooper, C., 2002. A northern extension of the range of the euphausiid Nyctiphanes simplex into Canadian waters. Journal of Crustacean Biology 22, 206-209.

Tremblay, N., 2008. Variación estacional de los indicadores de estrés oxidativo asociada a la migración vertical de los eufáusidos subtropicales del Golfo de California. Master's Thesis, Centro Interdisciplinario de Ciencias Marinas, La Paz, B.C.S., Mexico.

Vidussi, F.H., Claustre, J.N., Bustillos-Guzman, C., Cailliau, Marty, J.C., 1996. Rapid HPLC method for determination of phytoplankton chemotaxinomic pigments: separation of chlorophyll $a$ from divinyl-chlorophyll $a$ and zeaxanthin from lutein. Journal of Plankton Research 18, 2377-2382.

Wilson, S.G., Meekan, M.G., Carleton, J.H., Stewart, T.C., Knott, B., 2003. Distribution, abundance and reproductive biology of Pseudeuphausia latifrons and other euphausiids on the southern Northwest Shelf, Western Australia. Marine Biology 142, 369-379.

Zavala-Hernández, C., 2007. Estrategias reproductivas en tres especies de eufáusidos (Crustácea: Euphausiacea) subtropicales en el Golfo de California. Bachaelor Thesis, Universidad Autónoma de Baja California Sur, La Paz, B.C.S., Mexico. 